\title{
A Guerra do Paraguai na historiografia brasileira: algumas considerações
}

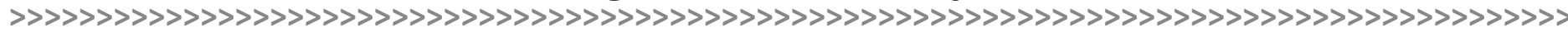

\section{Resumo:}

Este artigo trata da historiografia brasileira relativa à Guerra do Paraguai. Consideramos as quatro versões predominantes nessa historiografia, quais sejam: a versão que se deu logo após a guerra, versão esta propagada pelo exército brasileiro (a historiografia memorialístico-militar-patriótica); a historiografia propagada pelos positivistas ortodoxos; o revisionismo das décadas de 1960/70/80, com destaque para León Pomer (1979; 1980) e Júlio Chiavenatto (1983); e a corrente interpretativa chamada por alguns estudiosos de neo-revisionismo, com destaque para Francisco Doratioto (2002). Demos ênfase às duas últimas historiografias, apreendendo, sobretudo, as questões relacionadas às causas do conflito, e ponderamos a historiografia neo-revisionista produzida pelo historiador Francisco Doratioto.

\section{Palavras-chave:}

Guerra do Paraguai. Historiografia brasileira. Balanço historiográfico.

\begin{abstract}
:
The purpose of this article is to discuss the brazilian historiography concerning the Paraguayan War. We considered the four prevailing versions on this historiography, namely: the version that came shortly after the War, this version propagated by the Brazilian Army (the memorialistic and patriotic historiography); the historiography propagated by orthodox positivists; the revisionism of the decades of 1960s, 1970s, 1980s, with emphasis on León Pomer (1979; 1980) and Júlio Chiavenatto (1983); and the interpretative chain called by some scholars of neo-revisionism, with emphasis on Francisco Doratioto (2002). We gave emphasis to the two last historiographies, seizing, above all, the issues related to the causes of conflict, and reflecting the neo-revisionist historiography.
\end{abstract}

\section{Keywords:}

Paraguayan War. Brazilian historiography. Historiographical balance sheet.

Qual historiador não sonhou poder, assim como Ulisses, alimentar as sombras com sangue para interrogá-las? Mas os milagres da Nekuia não estão mais em voga e não existe outra máquina de voltar no tempo senão a que funciona em nosso cérebro, com materiais fornecidos por gerações passadas (BLOCH, 2001, p. 74).

* > Mestre em História pela Universidade Federal da Paraíba (UFPB). Doutorando em Educação pela Universidade Federa de Pernambuco (UFPE). Bolsista CAPES. andremendes.s@hotmail.com 
Em 1994, exatamente 130 anos após o início do maior conflito armado da América Latina, realizou-se no Rio de Janeiro, sob promoção da Biblioteca Nacional e apoio da Fundação Roberto Marinho e Banco Real, o Colóquio Guerra do Paraguai - 130 anos depois, organizado pelo professor Carlos Guilherme Mota. Em 1995, Maria Eduarda Castro Magalhães Marques (1995) organizou o livro Guerra do Paraguai: 130 anos depois, pela Editora Relume-Dumará, oriundo dos seminários resultantes desse colóquio, com alguns acréscimos de textos e informações bibliográficas e documentais.

Um desses artigos acima referido é o do historiador Carlos Guilherme Mota(1995), intitulado A Guerra contra o Paraguai: A História de um silêncio. Neste, o pesquisador disserta sobre o silêncio que a historiografia oficial relegou ao tema e afirma que tal esquecimento é devido à posição periférica da América Latina.

Mota afirma que, na historiografia da Guerra do Paraguai, "reside um nó histórico de nosso passado comum e traumático". E continua: "um nó histórico-ideológico que, uma vez desatado, permitirá talvez o arranque para um futuro crítico e democrático, no qual as disputas sejam equacionadas em fóruns internacionais legítimos, abertos e modernos" (p. 48). Contudo, acreditamos que nós históricos, utilizando-nos da própria expressão do autor, nunca são desatados definitivamente, como se a verdade fosse enfim chegar e, finalmente, iluminar os fatos obscuros da História.

Como se pode observar, a Guerra do Paraguai, ou Guerra Grande, como também é conhecida, é um assunto que tem gerado celeumas na historiografia brasileira. Desde o final da guerra, na década de 70 do século XIX, já começaram a ser produzidas interpretações desse acontecimento.

Em nossos estudos, localizamos quatro perspectivas historiográficas brasileiras em relação à Guerra do Paraguai: a memorialístico-militar-patriótica, a dos positivistas ortodoxos, a revisionista e a neo-revisionista. A análise que se segue das quatro vertentes historiográficas acerca da Guerra do Paraguai terá como ênfase as causas da guerra apresentadas pelas diferentes historiografias.

A primeira versão oficial é aquela propagada pelo exército brasileiro, que tinha como principal tendência apresentar o Brasil como o glorioso vencedor da guerra. Tais estudos privilegiavam, em seus enfoques, estratégias de guerra e enaltecimento de seus comandantes militares, a exemplo do Duque de Caxias e do Conde D`Eu. Cabe aqui lembrar que esse era o momento em que a escrita da História estava centrada nos grandes homens, nos chamados heróis nacionais. Nessa perspectiva, podemos perceber, de maneira mais evidente, a questão da identidade nacional intrincada nas narrativas desta vertente historiográfica.

Esse primeiro momento historiográfico se deu mais por uma narrativa memorialístico-patriótica daqueles que participaram da guerra do que por uma análise histórica propriamente dita. Nessas narrativas prevaleceu, via de regra, uma interpretação que apontava para o governo paraguaio como o causador da guerra, o responsável pelo conflito, pois, segundo esta visão, foi esse governo que invadiu/agrediu o Império do Brasil. Essa forma hegemônica de interpretação, que ganhou espaço no final do período imperial e perdurou por boa parte do período republicano, tendia a personificar a guerra na figura do presidente do Paraguai, Francisco Solano López.

A interpretação mencionada não responsabilizava diretamente o povo paraguaio, pois, conforme a mesma, a população desse país, assim como o Império brasileiro, também era vítima das ânsias do tirano megalômano, que tinha a intenção de expandir seus domínios para outras regiões, a exemplo do Rio da Prata. Cabe aqui lembrar, novamente, que o momento dessa escrita histórica foi a dos grandes homens, isso valia tanto para aqueles a serem enaltecidos, como demonizados. Assim, para essa primeira historiografia, a causa primordial da guerra passa a ser associada à figura de Francisco Solano López. 
Tendo isso em vista, quer dizer, o lugar-social de onde escreviam os autores desse período - hierarquia militar e Institutos Históricos -, não encaramos com tanto estranhamento, assim como fazem alguns historiadores, a perspectiva dessa primeira vertente historiográfica sobre a Guerra do Paraguai, qual seja: a da exaltação dos grandes heróis como símbolos da pátria/nacionalidade versus a demonização dos vilões, sempre associados ao outro. Assim posta, a guerra toma características de um conflito entre a civilização, entendida aqui como o Império brasileiro, e a barbárie, associada à República do Paraguai ${ }^{1}$.

Nesse tocante, Maestri afirma que:

A narrativa memorialista sobre a guerra contra o Paraguai foi produzida em geral por oficiais e profissionais liberais que participaram da guerra, sem grandes informações sobre suas razões profundas, sobre o Paraguai e sua sociedade e, não raro, sobre o próprio Império, uma entidade na época sobretudo política, devido à sua fortíssima regionalização (MAESTRI, 2009, p. 3).

A esse respeito, diz Doratioto:

Após tantos sacrifícios e dúvidas quanto à condução do conflito, passou-se a 'louvação das glórias militares do Brasil e do Império'. Por encomenda oficial, foram pintadas grandes obras tratando de momentos da guerra: A Batalha do Avaí, de Pedro Américo, e Combate Naval do Riachuelo, de Victor Meirelles. Chefes militares receberam títulos de nobreza e construiu-se, no plano narrativo, a epopeia da guerra (DORATIOTO, 2009, p. 3).

Acerca das ambiguidades de como passou a ser vista a Guerra do Paraguai nos primeiros anos do período republicano, diz Doratioto:

\begin{abstract}
A legitimidade da guerra passou a ser questionada pelos positivistas brasileiros, após o golpe militar que derrubou o Estado Monárquico em 1889, e instalou a República no Brasil. A nova realidade política era ambígua quanto a Guerra do Paraguai, pois os dois militares de maior patente que participaram do golpe, Generais Deodoro da Fonseca e Floriano Peixoto, haviam lutado no conflito com reconhecida bravura e não manifestaram dúvidas quanto a sua validade. Contudo, o novo regime republicano tinha embasamento ideológico positivista e intelectuais adeptos deste pensamento, coerentes com seu caráter pacifista, condenaram a Guerra do Paraguai. Eles também atuaram, assim como outros aderentes da República, com a finalidade de justificar a nova realidade política brasileira e uma forma de fazê-lo era criticando homens e acontecimentos da história do Brasil Monárquico, inclusive o conflito com o Paraguai (DORATIOTO, 2009, p. 4).
\end{abstract}

Uma segunda corrente historiográfica sobre a Guerra do Paraguai surgiu concomitantemente a primeira e estava relacionada às críticas que positivistas ortodoxos e republicanos fizeram das interpretações da corrente memorialístico-militar-patriótica. Os positivistas ortodoxos ${ }^{2}$, enquanto republicanos convictos, buscaram questionar os feitos do Império, pondo em xeque toda a política imperial. Nesse sentido, teceram profundas críticas em relação à atuação do Brasil na Guerra do Paraguai.

Nas primeiras décadas da instalação do regime republicano no Brasil, estabeleceuse certa ambiguidade acerca da Guerra do Paraguai, pois ao mesmo tempo em que os intelectuais positivistas ortodoxos brasileiros ligados ao novo regime, tentavam desconstruir a imagem dos feitos em relação ao conflito, inevitavelmente associados ao governo imperial, "personagens" que haviam participado da guerra ainda estavam vivos, relatando suas memórias, tecendo suas narrativas e interpretações acerca deste evento. Enquanto
1 > Ver, por exemplo: CERQUEIRA, 1980; DUARTE, 1981.

2 > Sobre a concepção dos positivistas ortodoxos em relação à Guerra do Paraguai, ver a obra de MAESTRI (2013). Como um importante pensador do positivismo ortodoxo, ver: MENDES (1920). 
estes últimos apresentavam uma história que valorizava as virtudes dos militares brasileiros que participaram da guerra, destacando sua importância para a História nacional, aqueles primeiros ensaiavam uma espécie de revisionismo histórico, apresentando o país guarani como vítima do governo imperial, contestando a importância e necessidade do conflito e pondo em xeque a política externa do Segundo Reinado (DORATIOTO, 2009).

Assim, o início da República é não somente marcado pelo confronto de ideais políticos entre republicanos e restauradores monarquistas, mas também pelo confronto de construções de uma História nacional, na qual a Guerra do Paraguai desempenhou um relevante papel $^{3}$. Entre discursos e contradiscursos em torno das explicações acerca da Guerra do Paraguai, teria prevalecido como abordagem mais usual, na historiografia brasileira, pelo menos até meados de 1960, a perspectiva memorialístico-militar-patriótica.

Em fins da década de 1960, foi desenvolvida uma terceira perspectiva sobre o conflito, que superou a historiografia nacional-patriótica, ao desconstruir os mitos criados por esta, cuja guerra era lembrada apenas como pretexto para comemorações das datas de grandes batalhas ou importantes personagens. Com uma perspectiva crítica em relação à historiografia anterior, suscitou novo ânimo às pesquisas sobre a Guerra do Paraguai. Contudo, é importante que se diga, ao tentar desconstruir mitos criados pela historiografia precedente, a historiografia revisionista findou por criar novos mitos, como o suposto desenvolvimento paraguaio do pré-guerra.

A abordagem revisionista teve como destacados autores o historiador argentino León Pomer (1980) e o jornalista brasileiro José Júlio Chiavenatto (1983). Em 1968, em Buenos Aires, Pomer publicou seu livro La Guerra del Paraguay - Gran Negócio!, traduzido para o português em 1980, com o título: A Guerra do Paraguai: a grande tragédia rio-platense. No Brasil, em 1979, Chiavenatto publicou Genocídio Americano, livro que seguiu a mesma linha interpretativa de Léon Pomer. Alguns historiadores, como Doratioto, apontam a obra de Chiavenatto como uma simplificação das leituras do historiador portenho.

Os subtítulos das edições dos livros de Pomer (1968; 1980) por si só já são bastante sugestivos. Na versão portenha do livro, podemos perceber que o subtítulo nos indica que a guerra não passou de um grande negócio, a pergunta é: um grande negócio para quem? Para qual país? Ou melhor, para que grupos sociais? Esta vertente historiográfica de fins da década de 1960 nos leva a analisar a guerra sob o prisma da influência do capitalismo internacional, com destaque para o imperialismo britânico na América Latina. Já o subtítulo em português nos sugere como imagem da guerra uma grande tragédia, e como toda tragédia, portanto, as vítimas, o povo paraguaio.

Hayden White (2006), em artigo escrito para o livro A Escrita da História, organizado por Jurandir Malerba, levanta interessantes questionamentos no que concerne ao estudo do desenrolar da Segunda Guerra Mundial. O autor interroga se o Nazismo e o Holocausto devem ser vistos sempre de uma maneira monolítica, analisados, portanto, em uma mesma direção, com um mesmo sentido.

O autor, muito criticado pela escrita de tal artigo, devido aos seus questionamentos acerca do Holocausto, defende a ideia de que estabelecer um gênero narrativo que privilegie a tragédia significa que o autor em questão quer que sua estória tenha um herói ou que seja uma estória heroicizada.

Assim, no nosso entender, White não questiona sobre a existência do massacre aos povos de origem judaica. O autor se questiona apenas acerca da forma narrativa unilateral e monolítica que se estabeleceu para se escrever sobre o Holocausto, narrado quase sempre sob a forma de tragédia. Contudo, questionamo-nos: como analisar o extermínio de mais de seis milhões de judeus de outra forma, senão a da tragédia? A partir de então, poderíamos nos questionar: seria a História puro discurso? Seria a escrita da História, portanto, uma questão puramente estilística? Acreditamos, no entanto, que o discurso 
Tal questionamento é válido para pensarmos também a Guerra do Paraguai, pois grande parte dos estudos realizados acerca desse acontecimento, sobretudo àqueles localizados entre as décadas de 1960 a 1980, valorizou esse tópico. Temos inclusive, como anteriormente exposto, autores que se referem à Guerra do Paraguai como a grande tragédia rio-pratense ou mesmo o genocídio americano. Entretanto, e seguindo o mesmo raciocínio do parágrafo anterior, como tratar de uma temática que envolve a dizimação de um povo, senão através da tragédia? A perda de parte considerável da população masculina paraguaia, a ponto de ser considerado um país de idosos, mulheres e crianças após a guerra, não seria, em si, uma tragédia? Deveríamos, então, resumir todos esses eventos ao discurso e considerar a tragédia como puro recurso estilístico, um enredo descolado do mundo real?

A vertente historiográfica revisionista aponta para o imperialismo, sobretudo aquele realizado pela Grã-Bretanha, como o principal motor da guerra. Há, nas análises desta historiografia, a relevância das causas econômicas, oriundas do capitalismo internacional. Para Chiavenatto:

\begin{abstract}
Os pretextos serão vários, a mentira será usada largamente e prevalece até nossos dias. As causas fundamentais para a destruição do Paraguai, é bom ressaltar, são nitidamente econômicas. O que não impede que surjam outros motivos paralelos que determinaram a guerra de extermínio à república guarani como: questões de limites, acidentes políticos e diplomáticos forjados, calúnias manipuladas dentro das embaixadas e até uma grotesca cruzada civilizatória para "libertar" o Paraguai dos seus tiranos. (CHIAVENATTO, 1983, p. 35, grifo do autor).
\end{abstract}

Contudo, apesar da indicação da causa econômica, em que o imperialismo britânico apresentou um papel fundante, o autor não impõe exclusivamente às elites econômicas desse país a causa da guerra, pois reconhece a atuação das elites locais como agentes que favoreceram a penetração e exploração da potência britânica na região. Assim, afirma Pomer:

Não tivemos um governador inglês, nem tropas de ocupação, mas quem poderia afirmar que nossa vontade sempre foi livre e soberana? A Grã-Bretanha nem sempre abriu mercados a tiros de canhão; soube combinar habilmente carícias com agressões. Neste caso, os cúmplices nativos pouparam à Grã-Bretanha o gasto com administração colonial e com soldados. (POMER, 1980, p. 17).

Com isso, percebemos que a interpretação deste autor não aponta diretamente para o governo britânico pelo desencadear da guerra, mas sim para as contradições do capitalismo:

A guerra foi financiada pela Inglaterra, mas não foi causada por ela e nem, provavelmente, incentivada ou desejada. A primeira potência da época não precisou mandar exército e nem dar ordens precisas, para que o conflito acontecesse. A ação do capitalismo se fez sentir pelo canal das contradições existentes (algumas delas já muito antigas). (POMER, 1980, p. 23).

As interpretações defendidas por Pomer e Chiavenatto suscitaram, a alguns estudiosos que trataram do tema, interessantes questionamentos. Talvez um dos mais relevantes seja considerar a Guerra do Paraguai, que aconteceu em solo latino-americano e cujos países diretamente envolvidos eram também países latino-americanos, como uma guerra gerada por um país do outro lado do atlântico, a Inglaterra. Para esses intelectuais, buscar um agente exógeno para explicar a Guerra do Paraguai é desestoricizar a América Latina. É restringir-lhe a capacidade de produzir suas próprias guerras. As raízes de tal expli- 
cação, ainda nessa perspectiva, podem ser encontradas em um pensamento colonialista que persiste entre nós, em que todos os avanços e problemas enfrentados pelas antigas colônias são reportados aos países europeus. Assim, diz Doratioto:

[...] o leitor desavisado pode concluir que a história do continente não se faz ou não se pode fazer aqui, pois os países centrais tudo decidem inapelavelmente. Os latino-americanos, nessa perspectiva, deixam de ser o sujeito de sua própria história, ou, na melhor hipótese, veem negado seu potencial de ser tal sujeito. (DORATIOTO, 1991, p. 69).

Consideramos tais questionamentos bastante significativos, afinal de contas não podemos perder de vista que a Guerra do Paraguai foi um conflito latino-americano. Contudo, devemos ressaltar que o ponto central da interpretação de Pomer é classista, isto é, sua intenção não é desestoricizar as ações dos latino-americanos. Em verdade, esta vertente defende que as elites inglesas, em conluio com as elites latino-americanas foram, em grande medida, responsáveis por este conflito. Assim, Pomer não impõe todos os encargos pelo desencadear do conflito platino à influência britânica. Basta ler a apresentação da obra Os Conflitos da Bacia do Prata, deste mesmo autor, cuja edição data de 1979, para perceber que muitas das críticas produzidas a partir da década de $1990 \mathrm{em}$ relação a historiografia revisionista não destacaram tal perspectiva dessa teoria. Assim:

No espaço geográfico e humano dos quatro Estados veremos um rosário de misérias e de agressões que não devem ser atribuídos invariavelmente à influência estrangeira de cuja existência damos conta permanentemente - porque isto seria cometer uma injustiça com os grupos dominantes locais ou oligarquias nativas: seria lhes negar capacidade para o exercício da rapacidade.

Um dos traços proeminentes que marcam os conflitos reside nisto: para afirmar a própria dominação faz-se necessário debilitar - ou destruir - o vizinho. Para crescer e fortalecer-se é preciso evitar que os que vivem do outro lado da fronteira se fortaleçam e cresçam. Obviamente esta política faz a felicidade da potência europeia dominante na área; mas imputar a essa potência todas as culpas equivale a eximir de toda culpa e encargo aos arrogantes mandatários locais. (POMER, 1979, p. 7).

Na visão de Chiavenatto (1983), contudo, surgiu no Brasil e na Argentina uma nova classe social desligada/dissociada da nação e associada ao imperialismo inglês. Essa nova classe social é chamada pelo autor de "testas de ferro do imperialismo britânico" (p. 10-11). Os ingleses unem-se à burguesia mercantil ou à nobreza decadente dos países locais e inauguram na América do Sul um novo tipo de domínio, sem intervenções armadas. Nesse sentido, os Estados do Brasil e da Argentina, eram "meras extensões imperialistas" da Inglaterra. Deste modo, apesar de destacar a atuação das elites locais, no desenrolar do conflito, Chiavenatto as apresenta, assim como os seus correspondentes governos, como fantoches dos desejos das elites imperialistas da Inglaterra, de maneira, muitas vezes, maniqueísta.

As incoerências e anacronismos produzidos por esta vertente historiográfica, mormente àquelas relacionadas à obra de Chiavenatto (1983), não apagam a importância desse momento na construção de uma História da Guerra do Paraguai, sobretudo por representar uma desconstrução da narrativa memorialístico-patriótica e reavivar, de forma crítica, as pesquisas relacionadas a essa temática.

Em meados da década de 1980, nos centros de produção do conhecimento histórico, começou a emergir uma quarta perspectiva historiográfica para tratar do assunto, que ficou conhecida, genericamente, como neo-revisionismo. Esta perspectiva aglutinou 
diversas pesquisas acadêmicas, com variados enfoques sobre a Guerra do Paraguai, mas que apresentam algumas características em comum: questionam a participação e responsabilidade inglesa no conflito; questionam o desenvolvimento econômico do Paraguai; apresentam como razões para a Guerra os conflitos e interesses regionais. Destacamos aqui as obras dos professores(as) Luiz Alberto Moniz Bandeira (1982), Ricardo Salles (1990), Francisco Doratioto, Alfredo da Mota Menezes (1998; 2012) André Toral (2001), e Ana Paula Squinelo (2002), apenas para registrar alguns exemplos.

Destacamos que, para este quarto momento, nossa intenção não é discutir, no curto espaço aqui reservado, a vertente historiográfica do neo-revisionismo, de uma maneira geral, mas sim destacar e ponderar alguns aspectos centrais nas ideias suscitadas por um de seus autores, o professor Francisco Fernando Monteoliva Doratioto.

Segundo Doratioto, “[...] as origens do conflito se encontram no processo de construção e consolidação dos Estados Nacionais no Rio da Prata e não nas pressões externas dos ingleses" (2004, p. 18). Ainda acerca das celeumas geradas pela historiografia, em particular sobre o suposto desenvolvimento paraguaio, o autor diz o seguinte:

\begin{abstract}
A interpretação imperialista apresentava a sociedade paraguaia do pré-guerra como avançada, liderada por Francisco Solano López, governante autoritário, mas preocupado como o bem-estar do seu povo. Nada mais distante da realidade. O Paraguai tinha uma economia agrícola, atrasada; nela havia escravidão africana, embora diminuta, e López era movido apenas pela lógica de todos os ditadores, a de se manter no poder (DORATIOTO, 2004, p. 18).
\end{abstract}

E continua, criticando a historiografia precedente:

\begin{abstract}
Outro mito que caiu por terra foi a suposta rivalidade do Paraguai com os ingleses. Vai contra a lógica histórica responsabilizar o imperialismo inglês pelo desencadear da guerra. Na realidade, o governo paraguaio mantinha boas relações com a Inglaterra, onde, desde o final dos anos 1850, contratou técnicos, com a finalidade de modernizar suas instalações militares. Era, sim, o Império do Brasil que tinha atritos com a Inglaterra, com a qual rompeu relações diplomáticas em maio de 1863. Elas somente foram restabelecidas, após recuo do governo britânico, em setembro de 1865, meses após o início do conflito. (DORATIOTO, 2004, p. 18).
\end{abstract}

Nesse contexto, o revisionismo da década de 1990 objetivava, segundo o próprio Doratioto, ponderar a historiografia corrente nas três décadas anteriores, que se caracterizou por produções de obras que tentavam denunciar arbitrariedades, autoritarismos e imperialismos de toda ordem que oprimiam, sobretudo, o povo dos países mais periféricos.

Deste modo, com o arejamento do cenário político brasileiro, através do término do estado de exceção, e a consequente redemocratização, apresentaram-se, segundo esse autor, obras que fugiam do binômio colonizador-colonizado, opressor-oprimido ${ }^{4}$. Assim, há uma revisão do revisionismo das décadas de 1960/70/80 acerca da Guerra do Paraguai.

Nesse sentido, a própria expressão de Doratioto (2004), ao afirmar que na década de 1990 surgiu uma nova luz sobre a Guerra do Paraguai, é bastante temerária, pois desconsidera toda a historiografia precedente, além de afirmar, implicitamente, que a verdade chegou para iluminar os fatos, apresentando a corrente de pensamento anterior como errônea, ou mesmo falaciosa. É inegável a contribuição historiográfica da obra de Doratioto, mas não podemos considerá-la como sendo a interpretação que desvendou/iluminou a verdade sobre a Guerra do Paraguai, desconsiderando assim as interpretações anteriores.

Em breve análise da obra de Chiavenatto, Doratioto diz:
$4>$ Importante obra que trata desse binômio é a do jornalista Eduardo Galeano (1983), As Veias Abertas da América Latina. Seu livro baseia-se na ideia de que, na divisão internacional do trabalho, há um lado que se especializou em perder e outro que se especializou em ganhar Afirma ainda que o local que hoje chamamos América Latina, precocemente especializou-se em perder. 
[...] ele mesmo [Chiavenatto] reconhece nesse livro [Genocídio Americano] que seu caráter é jornalístico, escrito com "paixão" e não com critérios metodológicos historiográficos. No entanto, apesar da honestidade do autor em fazer essa declaração, os revisionistas brasileiros e de países vizinhos o citam como se fosse um trabalho historiográfico. (DORATIOTO, 2009, p. 7, grifo nosso).

Isso demonstra certo preconceito de Doratioto acerca de obras produzidas por outros profissionais que não os da História, como se nós, historiadores de formação, detivéssemos toda a prerrogativa da produção do conhecimento histórico. Devemos pensar que a História enquanto curso superior, que possibilitasse a formação do historiador, só surgiu no Brasil em meados de 1930, sendo jornalistas e advogados, sobretudo, profissionais que escreveram obras de grande relevância para a historiografia brasileira antes desse período, e mesmo depois dele 5 .

Neste sentido, a preocupação principal de Doratioto é desqualificar a obra de Chiavenatto antes mesmo de analisá-la. A intenção do autor é passar a ideia aos seus leitores de que as obras revisionistas, sobretudo Genocídio Americano, são totalmente descabidas, ou, utilizando a própria expressão do autor para se referir ao revisionismo histórico acerca da Guerra do Paraguai, baseando-se num verso do compositor Cazuza: "As suas ideias não correspondem aos fatos" (DORATIOTO, 2009, p. 9).

Em contrapartida, ao se referir à obra Genocídio Americano, Maestri afirma:

Em março de 1979, com Genocídio americano: a Guerra do Paraguai, o jornalista Júlio José Chiavenatto, retomando algumas das teses revisionistas, superava as apresentações factuais nacional-patrióticas com ampla discussão das razões do confronto, apresentando como agressão do Império contra a nação e o povo paraguaio, em vez de produto da vontade de líder desvairado. Lançado dias após a posse do último general-ditador, o estudo conheceu enorme consagração. O livro teve 39 edições; tradução ao espanhol; edições piratas no México e no Paraguai [em guarani].

O livro tornou-se referência da historiografia brasileira, pautando os futuros estudos e debates sobre a Guerra. A redação para o grande público, sem notas de rodapé, em linguagem jornalística erudita, facilitou o enorme acolhimento, determinado sobretudo pelo momento da publicação, que condicionou a própria feitura do trabalho. As sequelas da crise mundial de meados de 1970 embalavam a retomada das mobilizações sindicais e democráticas, trincando a hegemonia construída pela ditadura.

Chiavenatto desconstruía a grande narrativa militar-patriótica da história do Brasil, em 1979, ano em que a retomada das lutas sindicais alcançou o apogeu, colocando o mundo do trabalho como referência por mais de uma década no país. A nova realidade político-social exigia representações do passado interpretando as necessidades dos trabalhadores e criava condições para a sua recepção. (MAESTRI, 2009, p. 6, grifo do autor).

5 > Temos como alguns exemplos: Manuel Bonfim (1993; 1997), que obteve formação em Medicina e Psicologia, e exerceu a atividade de jornalista no Rio de Janeiro. Esse autor escreveu importantes obras sobre a História do Brasil e da América Latina. Caio Prado Júnior (1973; 2004; 2006), formado em Direito e Geografia, analisou o Brasil através de um pensamento dialético marxista. O próprio jornalista Eduardo Galeano (1983), citado em nota anterior, não escreveu sobre a História do Brasil especificamente, mas sua obra sobre a América Latina teve importante influência sobre os historiadores brasileiros. E, mais recentemente, acerca dos estudos sobre a Ditadura Militar no Brasil, Hélio Gaspari (2002a; 2002b; 2003; 2004).
Desta forma, com uma visão bem mais lúcida do que Doratioto acerca do movimento revisionista, Maestri assenta Genocídio Americano no seu contexto de produção e ressalta a relevância da obra como uma referência historiográfica brasileira. Contudo, Doratioto reconhece algum mérito na obra de Chiavenatto, ao afirmar:

Chiavenatto teve coragem pessoal ao publicar esse trabalho quando o regime militar, embora já promovesse a abertura política, ainda mantinha o sistema repressivo, e a ele cabe o mérito de ter revivido, naquele momento, o interesse sobre a Guerra do Paraguai. (DORATIOTO, 2009, p. 7).

Entretanto, Doratioto, desconsiderando a dinâmica do processo historiográfico, continua a sua crítica: 
A produção revisionista era militante, tendo como objetivo encontrar no passado elementos que permitissem confirmar sua visão do que deveria ser o mundo no presente e, principalmente, no futuro. Se os fatos históricos não se adaptassem a essa visão, fazia-se "releituras" deles ou, então, os ignorava. Foi desse modo que a sociedade paraguaia da época de López foi apresentada quase como uma sociedade protosocialista, cuja economia seria avançada e moderna (DORATIOTO, 2009, p. 9).

Doratioto, em sua desqualificação da historiografia revisionista, argumenta que esta segue uma perspectiva ideológica, militante. Deveríamos aqui destacar que não é somente a historiografia de esquerda que é militante, assim como nos faz entender Doratioto. De tal modo, fazemos dois questionamentos: há perspectiva historiográfica que não seja ela mesma ideológica? A historiografia nacionalista de direita não é militante e ideológica?

Maestri considera o dito neo-revisionismo como uma restauração historiográfica, um retorno às trincheiras:

Quanto à Guerra do Paraguai, movimento historiográfico restauracionista apoiado pelas forças sociais triunfantes e impulsionado pela mídia, desqualificou o revisionismo anterior como mero produto de ideologia "autoritária", populista", "socialista" etc., centrando as impugnações nos lapsos factuais e interpretativos, potenciados ao absurdo, sobretudo da obra de Chiavenatto, e ignorando os avanços obtidos e toda a produção que não se enquadrava às críticas restauracionistas. (MAESTRI, 2009, p. 7, grifo do autor).

Francisco Fernando Monteoliva Doratioto restaura/revigora, em certo sentido, a historiografia nacionalista anterior ao revisionismo histórico de Pomer e Chiavenatto. Assim, o epíteto de neo-nacionalista ou mesmo restauracionista, como denominou Maestri, talvez se enquadre melhor para caracterizá-lo do que neo-revisionista. É importante que se diga que Doratioto fala de um lugar institucional/social ${ }^{6}$ bastante específico, o Instituto Rio Branco, no qual é professor e orientador do Mestrado em Diplomacia 7 .

Em sua obra, publicada pela Companhia das Letras com o título Maldita Guerra: Nova História da Guerra do Paraguai, Doratioto, já no primeiro parágrafo da introdução, diz:

Entre 1740 e 1974, o planeta teve 13 bilhões de habitantes e assistiu a 366 guerras de grande dimensão, ao custo de 85 milhões de mortos. O resultado dessas guerras parece ter sido um premio à agressão, pois em dois terços delas o agressor saiu-se vencedor e, quanto a duração, $67 \%$ terminaram em prazo inferior a quatro anos. A Guerra do Paraguai faz parte, portanto, da minoria, pois o agressor, o lado paraguaio, foi derrotado, e a luta se estendeu por cinco anos (DORATIOTO, 2002, p. 17, grifo nosso).

O professor do Instituto Rio Branco já deixa bem clara, desde o primeiro parágrafo da obra, a sua concepção acerca do conflito. O agressor, quer dizer, o causador da guerra, foi o governo do Paraguai que invadiu o Brasil, tendo este, inevitavelmente, que retaliar. Desta forma, assim entendido o conflito, o governo brasileiro, aquele atingido pela agressão da República paraguaia, apenas defendeu-se do tirano megalômano que presidia aquele país. E continua, advogando em defesa brasileira:

A geração daqueles que lutaram na guerra, quer nos países aliados, quer no Paraguai, não registrava de forma positiva o papel histórico de Solano López. Havia certeza da sua responsabilidade, quer no desencadear da guerra, ao invadir o Mato Grosso, quer na destruição de seu país, pelos erros na condução das operações militares e na decisão de sacrificar os paraguaios, mesmo quando caracterizada a derrota, em lugar de pôr fim ao conflito (DORATIOTO, 2002, p. 19).
6 > Sobre lugar institucional/social, ver: CERTEAU (1982).

7 > Instituto Rio Branco é o responsável pela formação do corpo diplomático brasileiro, ligado ao Ministério das Relações Exteriores. O professor Francisco Doratioto, segundo informações do seu Currículo Lattes, atua no Instituto Rio Branco desde 1998. A partir de 2008, passou a integrar, também, o corpo docente do Departamento de História da Universidade de Brasília (UnB). 
Além de o autor afirmar a unanimidade acerca da percepção do papel histórico de Solano López entre aqueles que da guerra participaram, algo com toda certeza improvável e de difícil comprovação histórica, isenta o Império brasileiro de toda a responsabilidade pela guerra. Em sua visão ultranacionalista, Doratioto aponta López como o responsável, não só pelo conflito, mas também pela própria destruição do Estado paraguaio e dizimação de sua população. Assim, ao persistir na guerra, segundo esse autor, López selou, irremediavelmente, o destino do povo paraguaio. Deste modo:

[...] nela [guerra] [López] vitimou os próprios civis paraguaios, ao estabelecer a prática de terra arrasada, e esvaziou território, sob ameaça aliada, de todos os recursos humanos e materiais que poderiam vir a ter utilidade para o inimigo. A população paraguaia sofreu grande mortandade, ao ser obrigada a se deslocar pelo interior do país sem receber transporte, comida e abrigo. (DORATIOTO, 2002, p. 477-478, grifo nosso).

Assim, com este tipo de argumentação, Doratioto (2002) retira todo o sangue das mãos do Estado e forças armadas brasileiros e o põe em uma única mão: Francisco Solano López; pois, segundo este autor, os mortos em combate se constituíram em uma minoria se comparados àqueles que pereceram "[...] devido à fome, doenças ou exaustão decorrente da marcha forçada de civis para o interior, ordenada por Solano López" (p. 456). Para Doratioto, a apresentação deste governante como "ambicioso, tirânico e quase desequilibrado" pela historiografia tradicional "não estava longe da realidade e pode até explicar certos momentos da guerra, mas não sua origem e dinâmica” (p. 19).

Deste modo, apesar desse autor apontar como causa principal da Guerra do Paraguai os conflitos regionais relacionados ao processo de construção dos Estados platinos, ele retoma muitas das explicações e argumentações da historiografia tradicional, sobretudo àquelas relacionadas à figura de Solano López. Ademais, Doratioto estabelece como início do conflito, assim como fez os militares da historiografia memorialístico-patriótica, o evento do aprisionamento do navio brasileiro Marquês de Olinda e a invasão do Mato Grosso por forças paraguaias. Ao estabelecer este marco inicial do conflito, o autor, automática e contraditoriamente, desconsidera como causas da Guerra do Paraguai os conflitos anteriores relacionados à Região Platina, como as intervenções do Império brasileiro no Uruguai e Argentina por exemplo ${ }^{8}$.

Acerca das intervenções brasileiras nos Estados platinos, Doratioto afirma:

$8>$ É importante destacar que Doratioto trata em sua obra (2002) da questão das intervenções brasileiras no Uruguai e na Argentina. Contudo, ao estabelecer as investidas paraguaias ao Império como início do conflito, desconsidera, contraditoriamente, todos os acontecimentos anteriores relacionados/contextualizados à Guerra do Paraguai.
Para viabilizar a intervenção no Uruguai, a diplomacia imperial obteve o beneplácito do governo argentino. Ao promover a entrada de tropas brasileiras no Estado oriental em setembro de 1864, o governo imperial não esperava que o ato gerasse reação contrária significativa. Contudo, Solano López reagiu invadindo o Mato Grosso, em dezembro de 1984, e Corrientes, na Argentina, em abril de 1985. (DORATIOTO, 2002, p. 474, grifo nosso).

A afirmação acima faz com que Doratioto entre em contradição, pois na perspectiva inicialmente exposta por ele, o Paraguai foi o país agressor, enquanto que na citação em destaque o país guarani apenas reagiu a atitudes imperialistas do governo brasileiro. Daí a arbitrariedade em apontar o evento do aprisionamento do navio brasileiro Marquês de Olinda e a invasão de Mato Grosso por forças paraguaias como o marco inicial do conflito. Num outro trecho da mesma obra, continua: 
A oposição conservadora apontou como desaconselhável o aumento da extensão das fronteiras brasileiro-argentinas [no que se refere ao Tratado da Tríplice Aliança] e indicou, ainda, que $a$ independência paraguaia estaria ameaçada, pois o país guarani ficaria cercado a leste e a oeste por território argentino, numa espécie de abraço apertado. (DORATIOTO, 2002, p. 474-475, grifo nosso).

Ao comentar acerca dos eventos que resultaram no aprisionamento do navio Marquês de Olinda e da invasão do Mato Grosso por forças armadas do Estado paraguaio, diz Doratioto:

Solano López não compreendia como o Marquês de Olinda e o presidente do Mato Grosso seguiram viagem para essa província, "depois que o Brasil nos declarou guerra”, ao invadir o Uruguai mesmo depois do protesto paraguaio de 30 de agosto.

O Império não declarara guerra ao Paraguai, mas Solano López interpretava ou fingia crer que sim. A chancelaria paraguaia comunicou ao governo britânico que o Paraguai, capturando o marquês de Olinda, havia "respondido às hostilidades iniciadas pelo Brasil sem prévia declaração de guerra”, dando a entender, em evidente falsificação, que houvera um ataque brasileiro a alvo paraguaio. O governo imperial e a opinião pública brasileira consideraram a captura um ato traiçoeiro de Pirataria. (DORATIOTO, 2002, p. 66, grifo do autor).

Assim, apesar de Doratioto apontar que o governo paraguaio entendia como um insulto, ou mesmo um perigo iminente a visita do Marquês de Olinda em águas paraguaias, devido à declaração de guerra que o governo imperial teria feito a esse Estado ao invadir o Uruguai, o mesmo considera que López teria fingido tal interpretação, em evidente falsificação, pois, segundo o entendimento desse autor, o Império brasileiro não teria declarado guerra ao Paraguai apenas por invadir o Uruguai.

Entretanto, é evidente que a aliança entre os governos do Uruguai e do Paraguai era uma forma de equilíbrio de forças na Região do Prata e que o Império brasileiro, ao invadir o Uruguai, rompe com esse equilíbrio, deixando o Estado paraguaio em situação de vulnerabilidade. Assim sendo, diferentemente de Doratioto, não entendemos que a interpretação de López ao considerar que o Estado brasileiro lhe havia declarado guerra seja um falseamento. É preciso que entendamos que a geopolítica da Região platina era muito mais complexa do que a apresentada por Doratioto.

A década de 1990 foi palco de acaloradas discussões acerca da Guerra contra o Paraguai. O colóquio realizado no Rio de Janeiro, mencionado nos primeiros parágrafos desse texto, é uma amostra dessas altercações. O neo-revisionismo não é a última palavra acerca da Guerra do Paraguai. Nem poderia ser, pois com a mudança do tempo presente, o passado e o futuro também são rearticulados. Essa é a dinâmica historiográfica e os historiadores estarão sempre envoltos na contínua tarefa de reescrever a História.

Desta forma, a partir das reflexões apresentadas até aqui, podemos afirmar, para o bem próprio do conhecimento histórico, que estamos longe de encerrar esta celeuma historiográfica. As discussões acerca do tema continuarão suscitando o debate e a reflexão. Como ponderamos anteriormente, o neo-revisionismo não é a expressão final sobre a Guerra do Paraguai, nem a nova luz que emergiu sob a historiografia, que finalmente veio para iluminar os fatos em definitivo. Ao contrário, qualquer pensamento neste sentido seria a-historiográfico. 


\section{Referências}

BANDEIRA, Luiz Alberto Moniz. O papel do Brasil na Bacia do Prata (da colonização ao império). Tese (Doutorado em Ciência Política)—Universidade de São Paulo, São Paulo, 1982.

BLOCH, Marc. Apologia da História ou O Ofício do Historiador. Tradução André Telles. Rio de Janeiro: Jorge Zahar, 2001.

BOMFIM, Manoel. América Latina: Males de Origem. Rio de Janeiro: Topbooks, 1993.

. O Brasil na América. Rio de Janeiro: Topbooks, 1997.

CERQUEIRA, Dionísio. Reminiscência da Campanha do Paraguai (1865-1870). Rio de Janeiro: Biblioteca do Exército, 1980.

CERTEAU, Michel de. A escrita da história. Tradução Maria de Lourdes Menezes. Rio de Janeiro: Forense-Universitária, 1982.

CHIAVENATTO, Júlio José. Genocídio Americano: a Guerra do Paraguai. 18 ed. São Paulo: Editora Brasiliense, 1983.

DORATIOTO, Francisco. A Guerra do Paraguai: 2a Visão. São Paulo: Brasiliense, 1991.

. História e ideologia: a produção brasileira sobre a Guerra do Paraguai. In: ENCUENTRO ANUAL DEL CEL, 5., 2009, Buenos Aires. Anais Eletrônicos...Buenos Aires: Museu Histórico Nacional da Argentina, 2008. Disponível em: <http://nuevomundo.revues.org/index49012.html $>$. Acesso em: 20 jul. 2009.

. Maldita Guerra. São Paulo: Companhia das Letras, 2002.

. Nova luz sobre a guerra do Paraguai. Revista Nossa História, Rio de Janeiro, ano 2, n. 13, 2004, p. 18-23.

DUARTE, Paulo de Queiróz. Os voluntários na guerra do Paraguai. Rio de Janeiro: Biblioteca do Exército, 1981.

GALEANO, Eduardo. As veias abertas da América Latina. Tradução Galeano de Freitas, Rio de Janeiro: Paz e Terra, 1983.

GASPARI, Élio. A Ditadura derrotada: o sacerdote e o feiticeiro. São Paulo: Companhia das Letras, 2003.

. A Ditadura encurralada: o sacerdote e o feiticeiro. São Paulo: Companhia das Letras, 2004. . A Ditadura envergonhada: as ilusões armadas. São Paulo: Companhia das Letras, 2002a.

. A Ditadura escancarada: as ilusões armadas. São Paulo: Companhia das Letras, 2002b.

MAESTRI, Mário. A guerra contra o Paraguai: História e historiografia: da instauração à restauração historiográfica [1871-2002]. In: ENCUENTRO ANUAL DEL CEL, 5., 2009, Buenos Aires. Anais Eletrônicos... Buenos Aires: Museu Histórico Nacional da Argentina, 2008. Disponível em: $<$ http://nuevomundo.org/index55579.html >. Acesso em: 15 de março de 2010.

FCM, 2013.

. A guerra no papel: história e historiografia da guerra do Paraguai (1864-1870). Passo Fundo:

MARQUES, Maria Eduarda Castro Magalhães (Org.). A Guerra do Paraguai: 130 anos depois. Rio de Janeiro: Relume-Dumará, 1995.

MENDES, Raimundo Teixeira. A Guerra do Paraguai. Rio de Janeiro: Edição J. B. Leal, 1920.

MENEZES, Alfredo da Mota. Guerra do Paraguai. Como construímos o conflito. São Paulo: Contexto; Cuiabá, MT: Editora da Universidade Federal do Mato Grosso, 1998.

. A Guerra é nossa: a Inglaterra não provocou a Guerra do Paraguai. São Paulo: Contexto, 2012.

MOTA, Carlos Guilherme. A Guerra contra o Paraguai: a História de um silêncio. In: MARQUES, Maria Eduarda Castro Magalhães (Org.). A Guerra do Paraguai: 130 anos depois. Rio de Janeiro: Relume-Dumará, 1995, p. 37-50. 
POMER, León. A Guerra do Paraguai: a grande tragédia rio-platense. Tradução Yara Peres. São Paulo: Global, 1980.

. Os conflitos da Bacia do Prata. Tradução Luiz Roberto Seabra Malta. São Paulo: Brasiliense,

1979.

PRADO JÚNIOR, Caio. Evolução Política do Brasil: Colônia e Império. São Paulo: Brasiliense, 2006. . Formação do Brasil contemporâneo: Colônia. São Paulo: Brasiliense, 2004

História econômica do Brasil. São Paulo: Brasiliense, 1973.

SALLES, André Mendes. A Guerra do Paraguai na literatura didática. Um estudo comparativo. Dissertação (Mestrado em História) —Universidade Federal da Paraíba, João Pessoa, 2011.

SQUINELO, Ana Paula. A Guerra do Paraguai, essa desconhecida... ensino, memória e história de um conflito secular. Campo Grande: UCDB, 2002.

TORAL, André. Imagens em desordem: a iconografia da guerra do Paraguai (1864-1870). São Paulo: Humanitas FFLCH USP, 2001.

WHITE, Hayden. Enredo e verdade na escrita da História. In: MALERBA, Jurandir (Org.). A História escrita: teoria e história da historiografia. São Paulo: Contexto, 2006, p. 191-210. 
